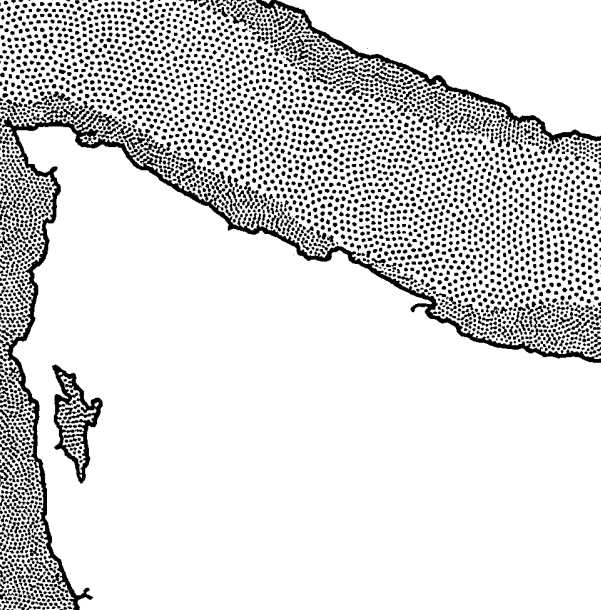

A COMPILATION OF ARTICLES CONCERNING RESEARCH SPONSORED BY

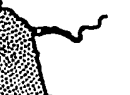
THE OFFICE OF NAVAL RESEARCH

Office of Naval Research

Contract Nonr-477 (10)

Project NR 083012
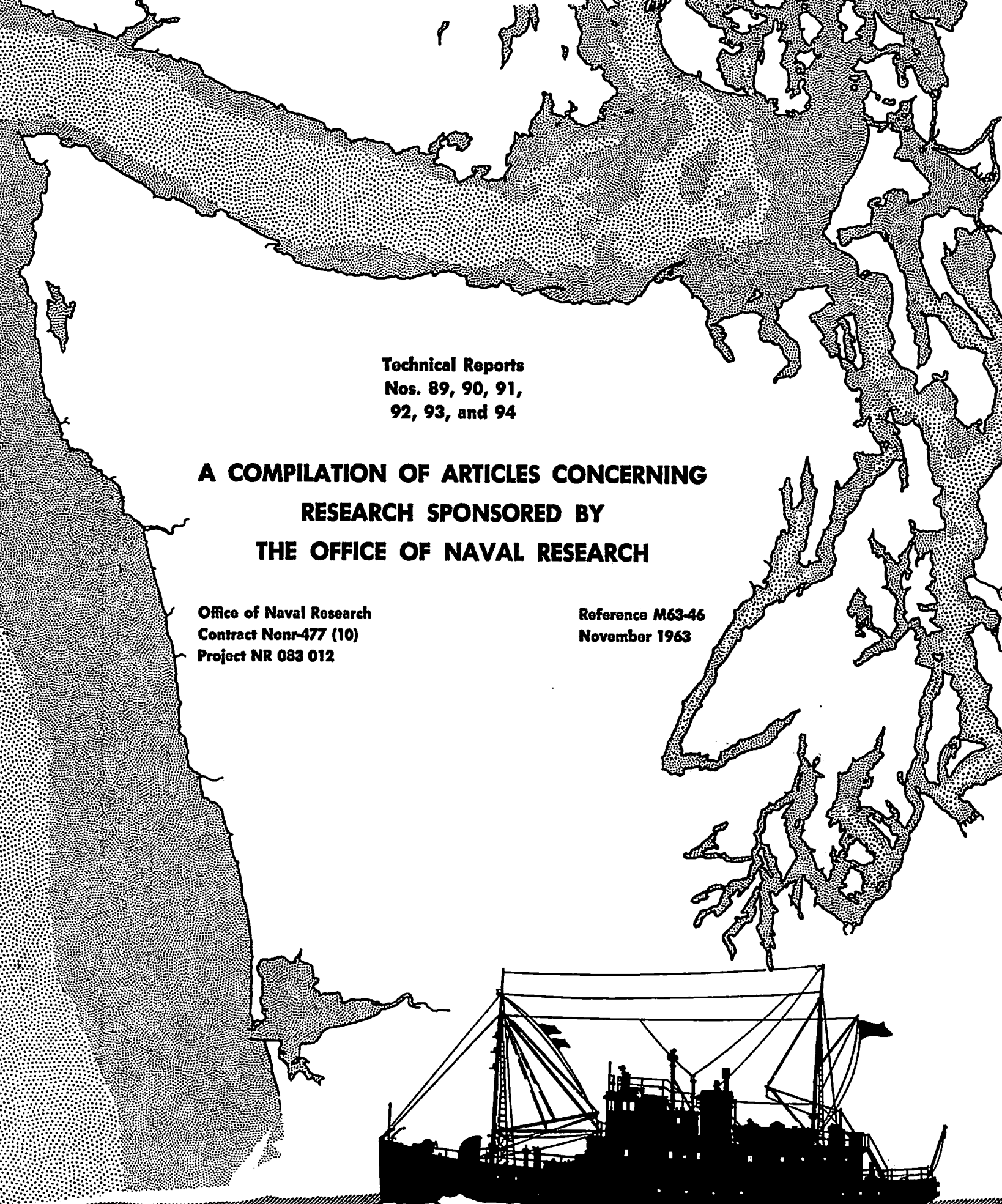
November 1963
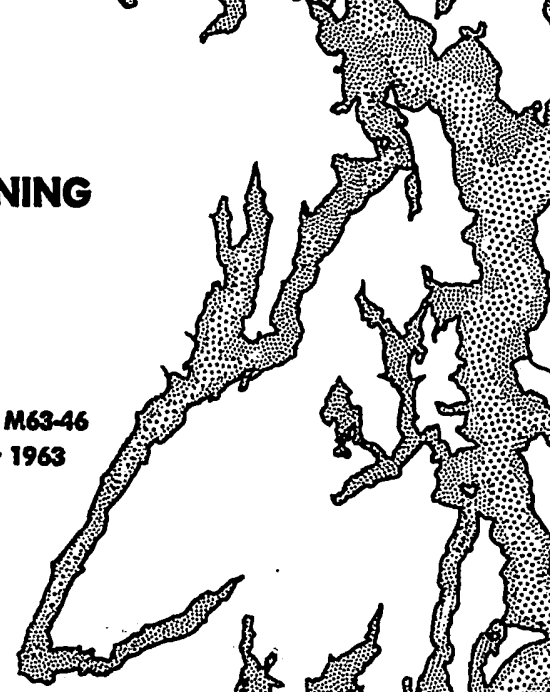


\section{UNIVERSITY OF WASHINGTON \\ DEPARTMENT OF OCEANOGRAPHY \\ Seattle, Washington 98105}

Articles Concerning Research Sponsored by the Office of Naval Researchs

Technical Report No. 89

ELECTRONIC DATA PROCESSING IN SEDIMENTARY SIZE ANALYSES, by Joe S. Creager, Dean A. McManus and Eugene E. Collias. Journal of Sedimentary Petrology, 32(4) 8833-839, December 1962 .

Technical Report No. 90

DISTRIBUTION OF IIVING PLANKTONIC FORAMINIFERA IN THE NORTHEASTEFP PACIFIC, by A. Barrett Smith. Contributions, Cushman Foundation, $I_{4}(1): 1-15$, January 1963.

Technical Report No. 91

A NEW HYPOTHESIS FOR ORIGIN OF GUYOTS AND SEAMOUNT TERRACES, by Y. Rammohanroy Nayudu. Crust of the Pacific Basin, Geophysical Monograph No. 6, pp. 171-180, December 1962 .

Technical Report No. 92

PHYSICAL AND SEDIMENTARY ENVIRONMENTS ON A LARGE SPITHTKE SHOAL, by Dean A. McManus and Joe So Creager. Journal of Geology, 71(4):498-512, July 1963.

Technical Report No. 93

GRAVITY AND THE PROPERTIES OF SEA WATER, by Ricardo M. Pytkowicz 。 Limnology and Oceanography, 8(2):286-287, April 1963.

Technical Report No. 94

POSTGLACIAI SEDTMENTS IN UNION BAY, ILAKE WASHINGTON, SEATTLE, WASHINGTON, by Dean A. McManus. Northwest Science, $37(2): 61-73$, May 1963.

Office of Naval Research

Contracts Nonr-477(10)

Project Nr 083012
Reference M63-46

November 1963

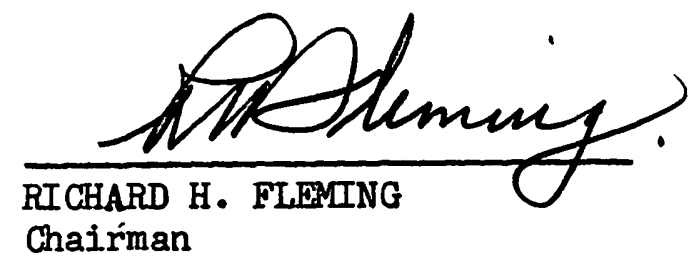

Reproduction in whole or in part is permitted for any purpose of the United States Government 


\section{PHYSICAL AND SEDIMENTARY ENVIRONMENTS ON A LARGE SPITLIKE SHOAL}

DEAN A. McMANUS AND JOE S. CREAGER

Reprinted for private circulation from THE JOURNAL OF GEOLOGY Vol. 71, No. 4, July 1963 Copyright 1963 by the University of Chicago PRINTED IN U.S.A. 


\title{
PHYSICAL AND SEDIMENTARY ENVIRONMENTS ON A LARGE SPITLIKE SHOAL'
}

\author{
DEAN A. MCMANUS AND JOE S. CREAGER \\ Department of Oceanography, University of Washington, Seattle 5, Washington
}

\begin{abstract}
Measurements of water temperature, salinity, transparency, current velocities, and sediment distribution are used to interpret the physical and sedimentary environments of a spitlike shoal extending 80 nautical miles north of the western tip of Seward Peninsula, Alaska. The shoal, covering approximately 2,000 square miles, is characterized by slopes of less than 31 feet per mile. Sediment-bearing coastal water passes northward through the Bering Strait and past the shoal at speeds of as much as $50 \mathrm{~cm} / \mathrm{sec}$. Four sedimentary environments have been recognized, and their significance with relation to the physical conditions is interpreted. The importance of seasonal variations is mentioned.
\end{abstract}

\section{INTRODUCTION}

From August 1 to September 2,1959, and from July 26 to August 28, 1960, the Department of Oceanography of the University of Washington carried out a general survey of the southeastern part of the Chukchi Sea (fig. 1).

Many oceanographic aspects of this broad, shallow embayment of the Arctic Ocean are transitional, inasmuch as this is the passage area for waters moving from the Pacific Ocean into the Arctic Ocean. The presence of several shoals, from a few to several tens of nautical miles in length along the eastern margin of the Chukchi Sea, suggests that sediment dispersal here is also in a state of transition. The eastern shoreline is dominated by a few prominent headlands, between which subdued tundra coastal areas lie. The shoals lie on the northerm side of the headlands.

The largest shoal is Cape Prince of Wales Shoal, extending northward for 80 miles from the eastern margin of Bering Strait (fig. 1). The large area and volume of this shoal, its location adjacent to the constriction formed by Bering Strait, the active movement of the water masses as reflected by the strong currents, and the relation of the distribution of sediment to the physical environment, all suggest an active area of

1 Contribution No. 259 of the Department of Oceanography, University of Washington. Manuscript received December 24, 1961. shoal development characterized by close correlation of physical and sedimentary conditions.

To better understand the correlation between these conditions, it is necessary to first examine each condition independently. Because the sedimentary environments are largely determined by the physical environments, the latter will be discussed first. The characterization of the physical environments is considered under the topics of bathymetry, temperature and salinity, currents, and water transparency.

\section{PHYSICAL ENVIRONMENT}

BATHYACETRY

Cape Prince of Wales Shoal is a large lobate feature, consisting of approximately $2 \times 10^{10}$ cubic meters $\left(7 \times 10^{11}\right.$ cubic feet $)$ of sediment, that forms a broad rise on the extremely flat floor of the Chukchi Sea (fig. 2, left). Near Cape Prince of Wales the depth of water above the shoal is less than 5 fathoms, but near the distal end of the shoal, where it attains a maximum width of about 30 miles, the water depth is almost 25 fathoms. Both lateral slopes of the shoal have a very low gradient. The steepest gradient on the western slope is only 31 feet per mile, and the eastern slope, having essentially the same gradient as the sea bottom northeast of the shoal, is less than 10 feet per mile. In general, a practically unmeasurable gradi- 
ent characterizes the bottom of the southeastern part of the Chukchi Sea.

\section{TEMIPERATURE AND SALINITY}

Because the deposits of the Chukchi Sea and Cape Prince of Wales Shoal are of clastic rather than of chemical or biochemical ori- gin, the temperature and salinity of the water do not directly effect sedimentation. However, these properties are important in identifying the sediment-bearing water masses. The distribution of temperatures at 5-meter depths indicates that a pronounced horizontal thermal gradient exists in the

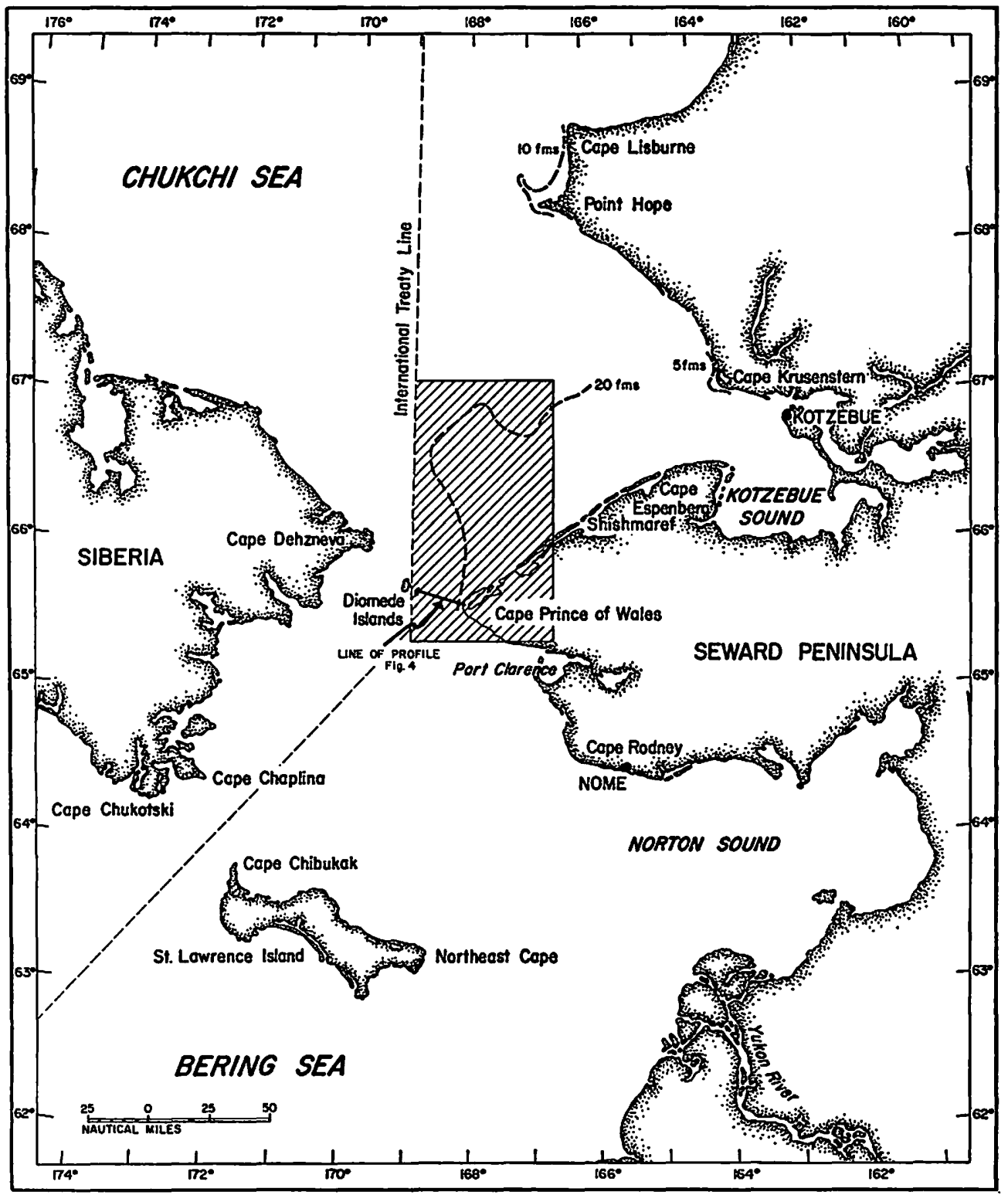

Frg. 1. - Index chart locating large shoals along southeastern margin of Chukchi Sea. Shoal at Cape Prince of Wales is defined by 20 -fathom isobath. Other shoals are defined by 5 - or 10 -fathom isobath. 


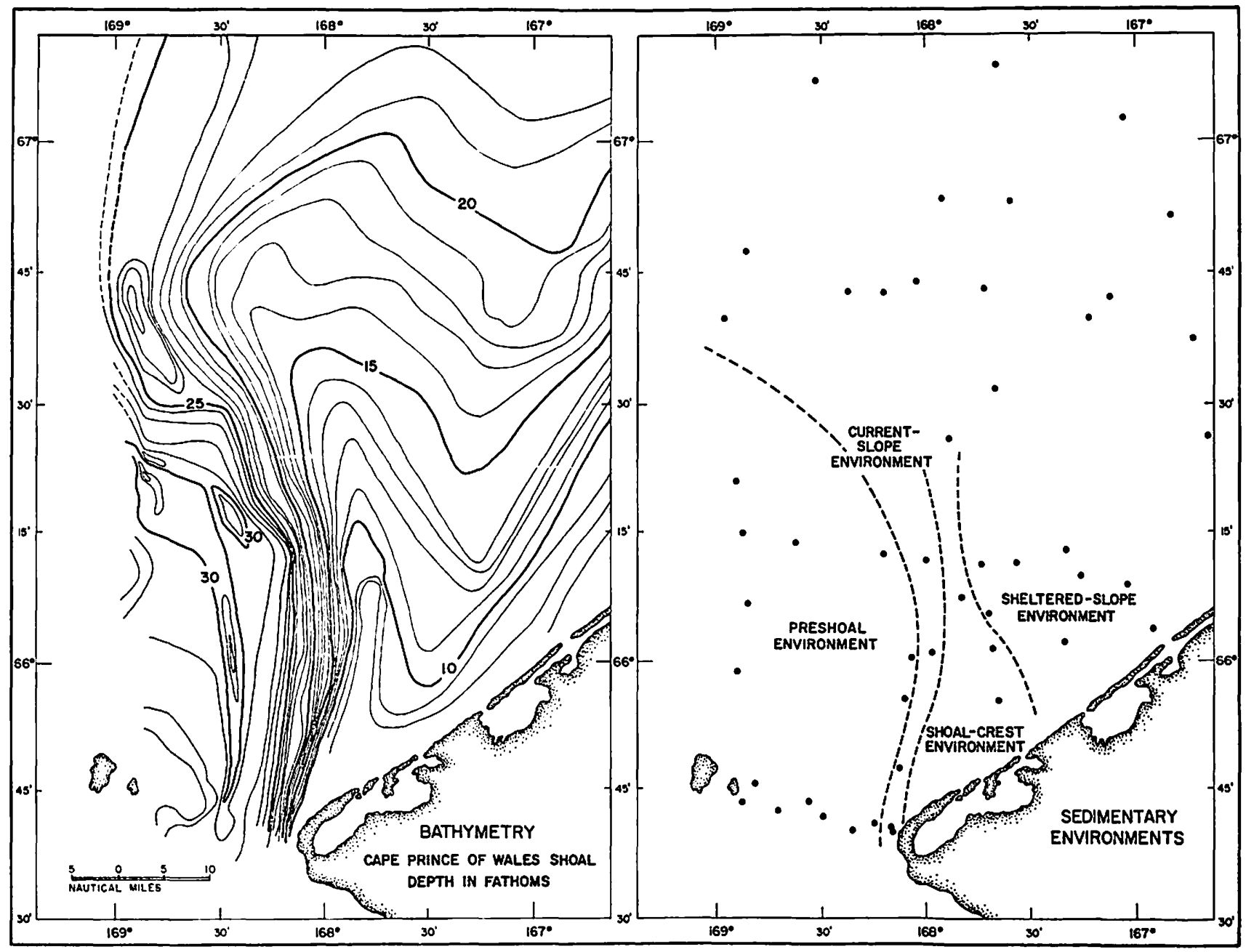

Fıc. 2.-Bathymetry and sedimentary environments of Cape Prince of Wales Shoal. Lefl, bathymetric chart showing spitlike shape of shoal; right, distribution of the four sedimentary environments. Note correlation of environments and bathymetry. 
southeastern part of the Chukchi Sea and the northeastern part of the Bering Sea. In general, the warmer water is along the coast and the colder water offshore. The 5-meter isotherms tend to follow the isobaths, even to the extent of developing a perturbation of warm water over and to the sheltered side of the shoal. At the bottom the isotherms also show a close correlation with the bathymetry, and the warmer water is near the coast and forms a perturbation on the north side of the headland of Cape Prince of Wales. It should be emphasized that these are summer temperature structures. The temperature structure should fluctuate seasonally, because the area is ice-covered for 7 or 8 months of the year.

Vertical temperature gradients typically reveal a thermocline separating warmer and nearly uniform surface temperatures from the cooler, uniform temperatures at depth (Fleming et al., 1959, p. 8). However, different vertical distributions were observed at stations near and over Cape Prince of Wales Shoal (fig. 3). Station 35, located near the Cape, represents the Alaskan Coastal Water, identified by Saur et al. (1954, p. 9), although with slightly different absolute values of temperature and salinity. Stations 34 and 49 are west of the shoal and indicate the overrunning of the deeper water by the warmer coastal water. Stations 40,43 , and 45 display isothermal relationships above and to the sheltered side of the shoal. Uniformity of temperatures from the surface to the bottom, far to the east, was also observed (Ozturgut, 1960, p. 23) near the coast between Shishmaref and Cape Espenberg.

The salinity structure in the Chukchi Sea roughly parallels that of the temperature. The less saline waters are near the coast, and irregularities in the salinity distribution of these waters are effected by the headland of Cape Prince of Wales. The vertical distribution of the salinity in the Chukchi Sea shows a similarity to that of the temperature, and typically, the halocline is at about the same depth as the thermocline. In relation to the shoal, the warm, less saline coastal water is shown overriding the cooler, more saline water west of the shoal (fig. 3), but isohaline, low-salinity water occurs over the shoal and to the northeast.

The temperature-salinity measurements indicate the presence of water masses that can be characterized by temperature and salinity relationships (Helland-Hansen, 1918). The two masses most important in this shoal development are the warm, relatively dilute, coastal water and the cooler, more-saline water offshore. The relationship between these two water masses is especially well shown by temperature-salinity profiles across the eastern part of Bering Strait (fig. 4).

\section{CURRENTS}

The distribution of mass in the water column, as indicated by the temperature-salinity relationships, is rela ted to a fairly strong current setting northward through Bering Strait (LaFond et al., 1949, p. 48). Early current determinations, made from dynamic computations, indicated a general northward surface flow of water in the Bering and Chuckchi Seas paralleling the coast and bottom contours (Barnes and Thompson, 1938, p. 66), but computed velocities were found to be less than observed velocities because the bottom waters were in motion toward the north.

The currents measured at 5-meter depth with Ekman and Gemware current meters during August, 1959, and with a modified Magnesyn current meter during August, 1960 , showed a northward set (fig. 5 , left). As shown by figure 5 , the highest speeds (those greater than $50 \mathrm{~cm} / \mathrm{sec}$ ) were recorded setting northwest, parallel to the coast, just south of the headland of Cape Prince of Wales and passing northward through the strait. The high speed at this location is thought to be due to convergence caused by the westward-projecting coastline (Fleming et al., 1960, p. 4). Over the shoal and northeast of the shoal, the currents have much lower speeds and show a greater variation in direction.

Currents measured to within 5 meters of 
the bottom proximate the direction of the surface currents, especially west of the spit (fig. 5, right). Although near-bottom measurements south of the Cape are unavailable, the currents at 20-meter depth are comparable with 20-meter depth currents in the strait, and indicate that the strongest near- bottom currents $(30 \mathrm{~cm} / \mathrm{sec}$ and higher speeds) occur in the same locations as do the strongest surface currents. Decreased speeds and a variety of current directions also characterize movement of the near-bottom water over the shoal.

Currents recorded in Bering Strait in Au-
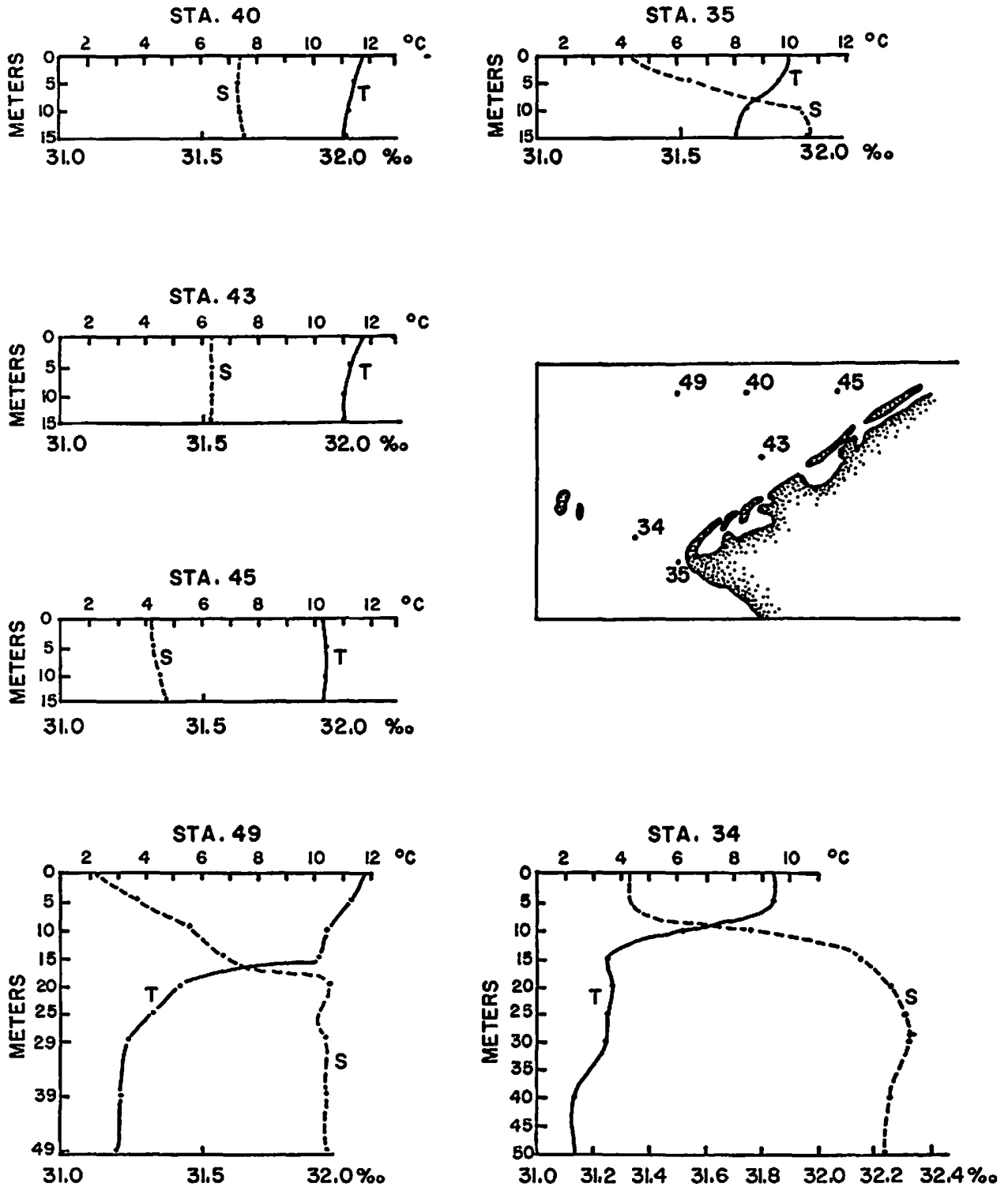

Fig. 3.-Vertical traces of temperature and salinity at selected stations on, and adjacent to, the shoal. A pronounced thermocline and halocline is indicated west of the shoal, whereas isopycnal water is present over the shoal and to the northeast. 
gust, 1960, after several days of brisk northerly winds, were weaker than those observed in August, 1959. Local winds probably "modify, rather than materially affect, the speed and direction of the movements on the surface layer" (Fleming et al., 1960, p. 4). Other current observations made in Bering Strait include a 21-hour station occupied with an Ekman meter (Barnes and Thompson, 1938, p. 66) and the stations reported by Ozturgut $(1960$, p. 12). These additional observations also suggest that, although the current through Bering Strait remains tion zone between the coastal water and the cooler, more saline, offshore water (Fleming et al., 1959, p. 6). The flow widens north of the strait, and it is here that the large Prince of Wales Shoal is found. The coastal water flowing over the shoal moves at a slower speed. A large, ill-defined eddy motion appears to be present on the sheltered northeast side of the shoal.

\section{WATER TRANSPARENCY}

A discussion of high-speed currents, particularly in the coastal water moving paral-

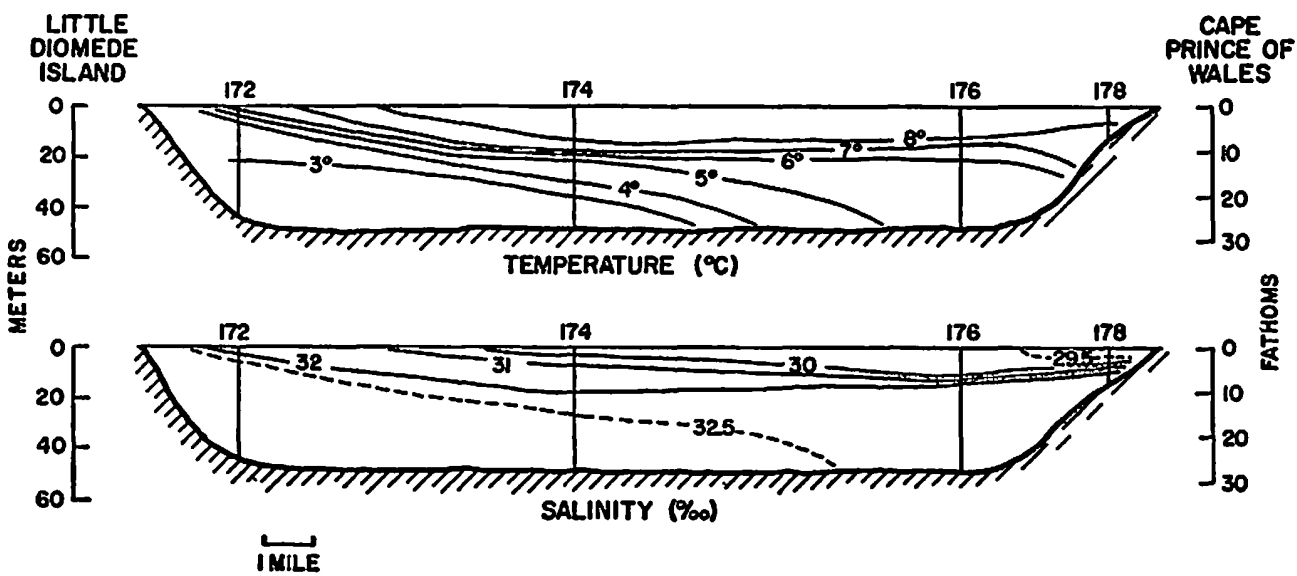

Fic. 4.-Temperature and salinity profiles across eastern Bering Strait. The coastal water is shown extending far westward as a plume from Cape Prince of Wales. The boundary between the coastal and offshore waters varies somewhat in sharpness and in distance from land.

strong, there are some variations in speed and direction. The greatest current variation is seasonal, for the water is ice-covered in winter, but measurements taken in February (Maksimov, 1945, p. 8) also showed a current setting northward through the strait, although the current speed was only one-fourth of that measured in August.

Thus, the currents are generally unidirectional, north from the Bering Sea past the spit and into the Chukchi Sea. Along the coast southeast of Cape Prince of Wales, a convergence of the warm, dilute coastal water occurs, producing high-speed currents throughout the water column which then move into the strait. The strongest currents in Bering Strait tend to occur in the transi- lel to the coastline, leads to a consideration of water transparency and thus of sediment transport. Although no direct measurements of sediment transport have been reported, a combination of studies, including bottom photography, hydrophotometry, and Secchi disk measurements, aid in giving a tenta tive picture of the distribution.

Bottom photography in the Chukchi Sea and northeastern Bering Sea has produced few good photographs because of the turbidity near the bottom throughout most of the area. The locations where relatively good photographs have been obtained, such as Bering Strait, were in areas of coarse bottom material (LaFond et al., 1949, p. 25).

In general, the transparency of the water 


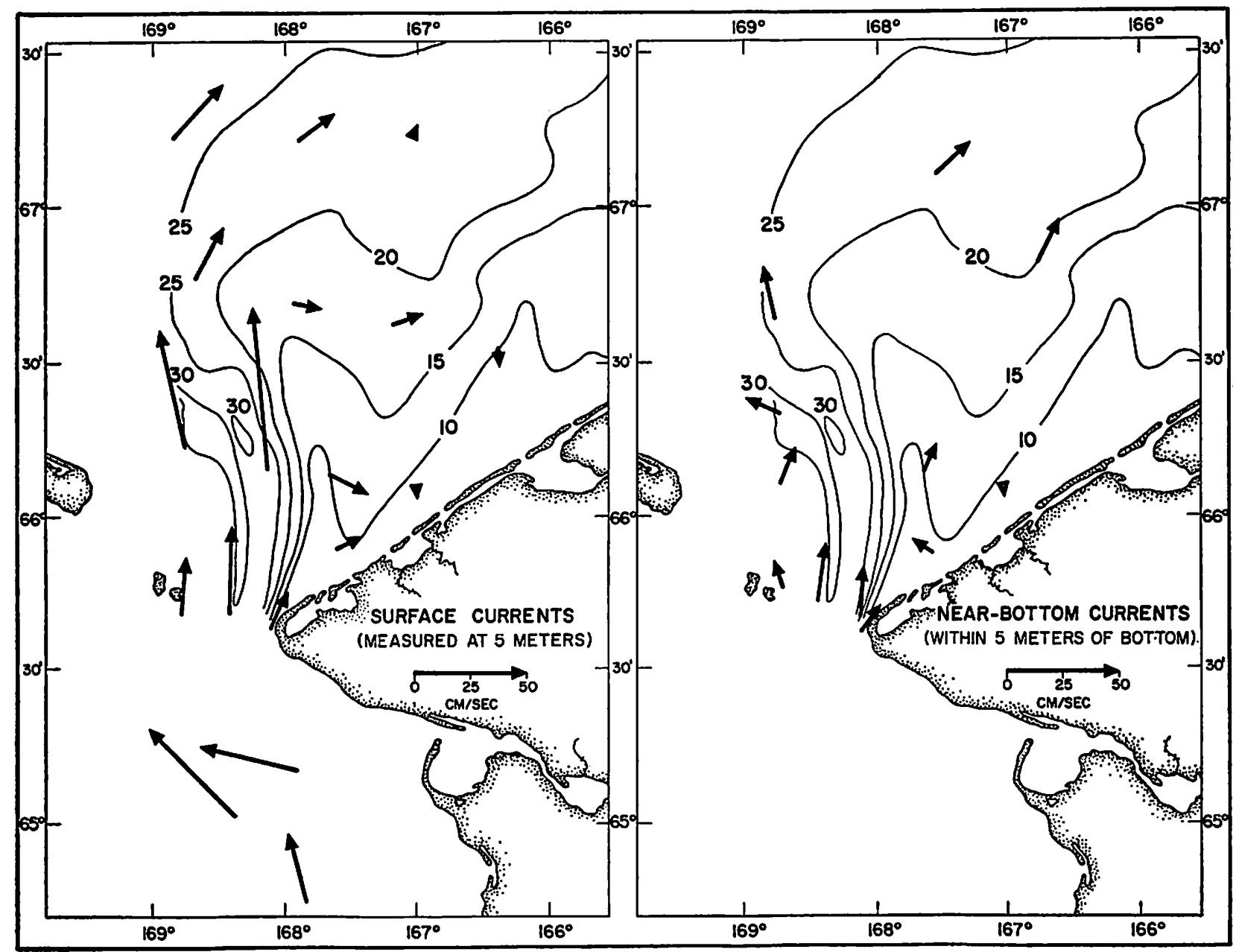

Fic. 5.-Surface and near-bottom current velocities. Left, currents at 5-meter depth; right, currents within 5 meters of the bottom 
decreased toward the shore. This opacity is due in part to particulate organic material, predominantly phytoplankton, and in part, especially near the bottom, presumably to suspended sediment. In some measurements organic matter was considered to be the probable cause of an opacity maximum occurring immediately above the thermocline (Buffington et al., 1950, p. 24).

At times, the surface coastal water southeast of Cape Prince of Wales is of varying shades of brown. Water samples taken from stations there contain a high concentration of silt particles in suspension. The boundary between this turbid water and the highly transparent offshore water may be extremely sharp, as was reported (LaFond $e t$ $a l ., 1949$, p. 81) on the eastern edge of Bering Strait where the boundary coincides with the transitional area of maximum horizontal temperature gradient.

Studies of water temperature and salinity, currents, water transparency, and estimates of the sediment content permit the identification of two water masses in the vicinity of Bering Strait, both of which pass northward through the strait. A warm, dilute, sediment-laden coastal water is found southeast of Cape Prince of Wales and passing around the Cape in the shoreward 2 to 3 miles. This water tends to override the cool, more saline, and more transparent offshore water, especially when it passes through Bering Strait. Upon emerging from the constriction of the strait, the water masses diverge, and this is the location of Cape Prince of Wales Shoal.

\section{SEDIMENTARY ENVIRONMENTS}

Up to now the shoal has been considered only as a bathymetric feature underlying the various physical environments, but fundamentally the shoal is a feature of sediment deposition. The distribution and variation of this deposition is reflected in the four sedimentary environments recognized at Cape Prince of Wales Shoal: (1) a preshoal environment, which is found in front of the shoal, (2) a current-slope environment, oc- cupying the western flank, (3) a shoal-crest environment, and (4) a sheltered-slope environment on the eastern slope (fig. 2, right).

\section{PRESHOAL ENVIRONMENT}

The preshoal environment is recognized in the area immediately west of the shoal, and therefore includes the eastern part of Bering Strait and the area just north of the strait (fig. 2, left). In Bering Strait, the mean grain size is in the granule and small pebble classes (fig. 6, left), but fine sands are found in the northern part of the preshoal environment and grade into the silts of the Chukchi Sea.

Most sediments in the adjacent areas are finer than the preshoal gravels, and the $1 \phi$ to $2 \phi$ class is the coarsest sediment occurring in all the environments. The distribution of the $2 \phi$ (medium sand) size grade (fig. $7, a$ ) best delineates the preshoal environment from the others, and shows the scarcity of coarse material outside this environment. Isopleths of finer material exhibit a reversal of this distribution. Silt comprises less than 5 per cent of the preshoal sample and clay-size particles are even less abundant, except along the eastern and northern margins of the area.

The sorting of the sediment is relatively uniform and very poor throughout the environment (fig. 6, right). In the strait and immediately northward, the very poor sorting is reflected by the gravel mode and a "tail" of sand. These samples show very positive skewness. As the mean size decreases to the north, a secondary mode appears in the sand size, reflecting the continued very poor sorting. Near the northern edge of the environment, however, this sand mode becomes dominant and, because only a few granules are present, the sorting is improved. The poorest sorting is along the eastern margin. These samples are bimodal, a mixture of preshoal gravel and the shoal sands. Because the adjacent current-slope environment is the one that more immediately reflects those processes which control deposition, discussion of the eastern part of 


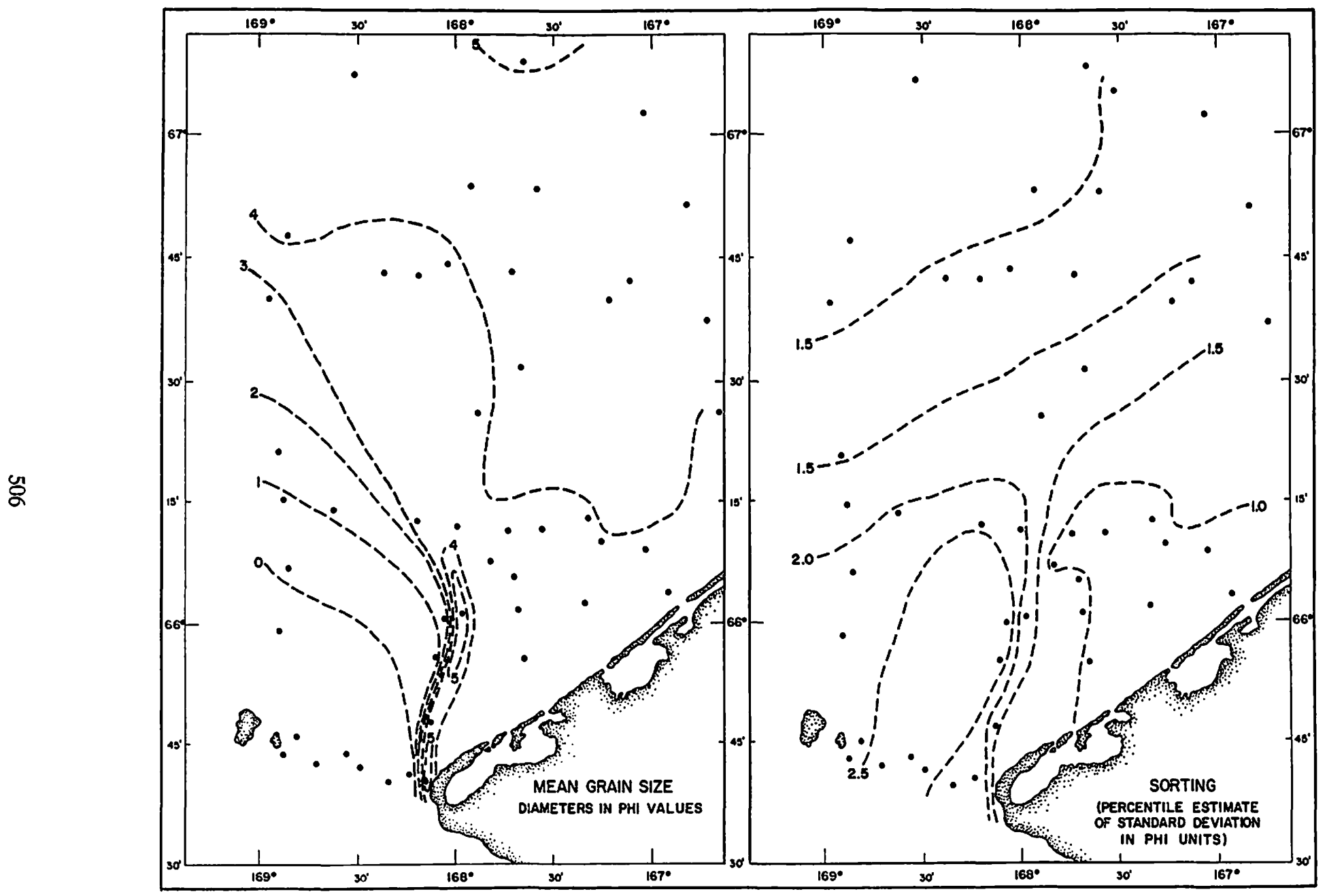

Fig. 6. -Grain size data. Left, chart of mean grain size showing narrow belt of coarse silt extending northward from the Cape; right, chart of sorting values showing the improved sorting on sheltered slope. 


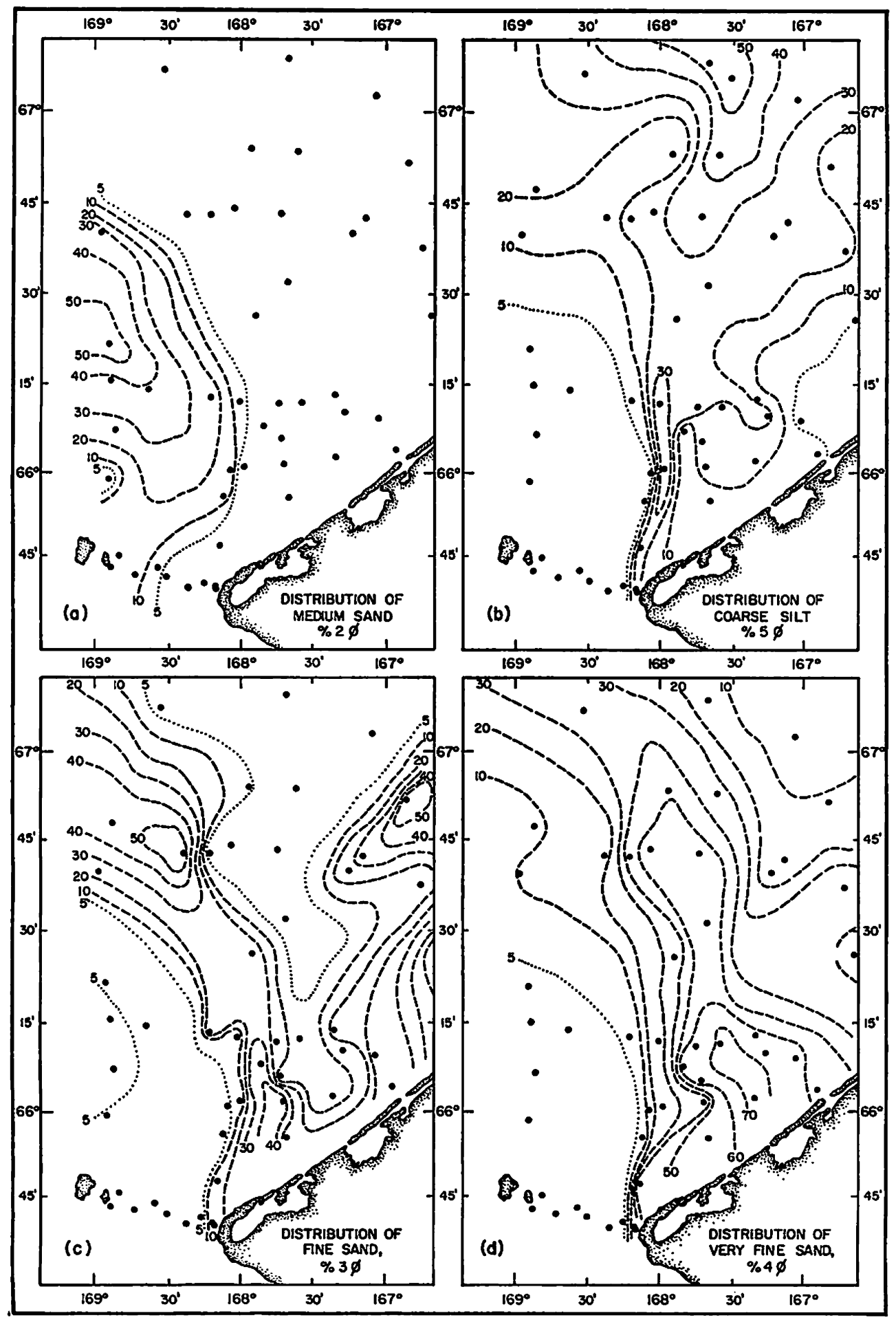

Frc. 7.- Isopleth charts of selected grain sizes: $a$, percentage of medium sand $(2 \phi)$ showing abundance of material in preshoal environment; $b$, percentage of coarse silt $(5 \phi)$ with maxima shown in current slope environment and on floor of Chukchi Sea north of the shoal; $c$, percentage of fine sand $(3 \phi)$ showing maximum on shoal crest; $d$, percentage of very fine sand $(4 \phi)$ with abundance of material distributed on sheltered slope. 
the preshoal environment will be included under the section on the current-slope environment.

For mineralogic discussion the gravels and the finer particles in the preshoal environment will be considered separately. The preshoal gravels consist of subangular pebbles of several varieties of sedimentary, metamorphic, and igneous rock types exposed on the mainland and on the Diomede Islands. This similarity of composition with the subaerial outcrops does not imply that the pebbles have been transported into the preshoal environment but rather that they are eroded remnants of bedrock that are very nearly in situ.

Subangular to angular grains of garnet and hornblende are the minerals most characteristic of this environment. The abundance of garnet is relatively uniform throughout the area, though a hornblende maximum occupies a belt along the western margin. This hornblende-garnetassemblage extends northward from the preshoal area into the central part of the southeastern Chukchi Sea; however, the assemblage is not as abundant in the shoal environments to the east. Another significant mineral, biotite, is very common in the northern part of the area.

An abundant benthic fauna is present in the preshoal area as shown by numerous shells and shell fragments in most of the samples. Pelecypods are the most common form, although barnacles, echinoids, crabs, and calcareous Foraminifera form a significant part of the fauna. Several species of Foraminifera are present, including many large forms, and although the same types are found in the rich fauna of the northeastern Bering Sea, they are not characteristic of the fauna in the Chukchi silts north of the preshoal environment.

The preshoal environment thus comprises a gravel-and-sand area sustaining a rich benthic fauna. The overriding coastal water does not directly effect the bottom environment of the preshoal area. Although nearbottom current speeds are sometimes greater than $20 \mathrm{~cm} / \mathrm{sec}$, the high transparency, the absence of sediment-laden coastal water, and the presence of rich benthic fauna all indicate that little silt or clay is being transported into the area. Although some sand has probably been introduced into the environment, most of the sand and the gravel is thought to be a lag residuum caused by the winnowing action of the strong currents. However, this lag is not considered to be a completely stationary deposit, for the tongue of the hormblende-garnet assemblage extending northward from the preshoal area suggests some northward movement of the sand. This movement, coupled with the lag origin, is also suggested by the slightly greater depths in the strait. This increased depth is possibly explained by the strong northward-setting current that could scour the bottom (LaFond et al., 1949, p. 17). It is possible that material transported through the strait west of the Diomede Islands is being deposited north of these islands. This condition is suggested by the influx of unaltered biotite in that part of the preshoal area.

\section{CURRENT-SLOPE ENVIRONHENT}

The current-slope environment occurs along the western slope of the shoal where gradients are about 31 feet per mile. The important aspect of this environment, therefore, is not the gradient but the characteristics of the current and the associated sediment transport.

The current-slope sediment is finer than any adjacent material, and mean grain sizes of samples of sediment here show fine sand to coarse silt (fig. $6, l e f l$ ). It should be noted that the isopleths along the southeastern part of the current-slope area are drawn with little control farther southeast, and are thus guided by the bathymetry. Even though the chart of mean grain size demonstrates a certain homogeneity in this area that is not present in the preshoal area, this homogeneity is better shown by the isopleths of $5 \phi$ material (fig. $7, b$ ). The coarse silt maximum identifies the current-slope environment.

Although the sediment is poorly sorted in 
this environment, it is decidedly better sorted here than in the adjacent preshoal area, because of the lack of a gravel mode. At the northern end of the area, however, the transitional contact with the preshoal area is shown by a slightly poorer sorting, caused by the presence of coarse lithic grains. These lithic grains also produce a negatively skewed distribution by "overbalancing" for the thin tail of fine particles characterizing the current-slope sediment.

Mineralogically, the current slope is characterized by an abundance of muscovite in the finer sands. This muscovite and a subordinate amount of chlorite are dominant over the hornblende. Micaceous silt is not only the main sediment type on the current slope, but it is also one of the dominant sediment types in the Chukchi Sea.

Even though shell fragments are found in the coarser grades of some of the samples, the benthic fauna here is not nearly as rich as that of the preshoal environment. One difference in the faunal composition is the presence of a few ostracodes in the current-slope area, but these organisms are even more characteristic of the shoal-crest environment. The Foraminifera of the current-slope area are distinct from those of the preshoal area. The number of species is greatly reduced and the significance of a species in the total population changes. For example, although Eggerella advena is present in the preshoal area, it forms only a small percentage of the population, while this species comprises about one-half the population in the current-slope area.

The distributions of the grain size and the mineralogical and faunal compositions delineate the current-slope sedimentary environment, which extends northward in a narrow belt from the tip of Cape Prince of Wales. Although the western margin of the environment represents in general the western edge of the shoal, the coincidence of this line with the western limit of direct bottom influence of the silt-laden coastal water is of greater genetic significance. Thus the current-slope environment is influenced by the coastal water, while the preshoal environment is influenced by the offshore water.

The tendency for the strongest currents to occur in the transition zone between the two water masses accents the importance of the water-mass controls in governing the western margin of the current-slope environment. This current control probably helps prevent the environment from becoming unrecognizable because of the divergence of the water nearer the Cape. Upon emerging from the orifice of Bering Strait, divergence and an accompanying decrease of speed are to be expected. These aspects are manifested to the east of the current slope, where divergence and the accompanying velocity drop exert a dominant control on the environments of the crest and of the sheltered side of the shoal. West of the current slope, a velocity gradient is not so apparent.

\section{SHOAL-CREST ENVIRONMENT AND SHELTERED- SLOPE ENVIRONAIENT}

The crest of the shoal represents a sedimentary environment distinct from that of the current slope, but it grades into that of the sheltered slope. Although the mean grain size of samples collected from both the crest and the sheltered slope is fine sand, the modal grades differ slightly. On the crest, the mode is very fine sand $(4 \phi)$ and is skewed toward fine sand $(3 \phi)$, although in places it is fine sand skewed toward very fine sand. On the sheltered slope, however, the mode of very fine sand $(4 \phi)$ is skewed toward coarse silt $(5 \phi)$. Some sediments with a silt mode are present on the sheltered slope.

The crest sediments are best delineated by isopleths of the fine sand grade (fig. $7, c$ ). In the crest sediments, the percentage of fine sand is significantly higher than it is in sediments from either slope, and this size grade there represents the coarsest material common to sediments from all three areas. When the next finest size grade is contoured (fig. $7, d$ ), the high percentage area shifts from the shoal crest to the sheltered slope. In the area east of the sheltered slope, the 
sediment trends indicate a transition into an area of different depositional controls.

The sorting of the crest sediments is varied but significantly better than that of the current-slope sediments. In certain places on the crest and sheltered slope, the sediment is poorly sorted owing to a greater abundance of both the coarser and finer materials, but no bimodal sediments are present. In other parts of the crest area, the sediment is well sorted, and throughout the sheltered-slope area moderate sorting prevails. This relatively high degree of sorting generally reflects distribution of grains in a single twograde mode. Not only are grades coarser than medium sand sparsely represented, but the slight positive skewness of the samples and a kurtosis that indicates near normalcy show that the sediment is only slightly less devoid of silt and clay than it is of the material coarser than fine sand.

The salient features of the mineralogical composition of this environment include a slightly higher percentage of subrounded fine and very fine sand-size quartz grains than are present on the current slope or in the preshoal area. However, the sediment remains a subangular sand. Muscovite and, to a less degree, chlorite and wood fibers form a significant part of the samples from the sheltered slope, especially in the upper part. The same heavy minerals that occur in the other areas are found, with the greatest abundance near the proximal end of the crest. In the lower part of the sheltered slope, an extremely low percentage of muscovite and chlorite, a greatly increased percentage of garnet, a slight improvement in rounding, and a general distribution of heavy minerals and grain sizes all suggest passage into a marginal environment.

The benthic fauna of the crest and sheltered-slope environments is very poorly developed. A large number of ostracodes is found along the crest of the shoal. Although these organisms form a minor part of the fauna on both slopes, they are exceptionally abundant on the crest and on the upper part of the sheltered slope. The macro-organisms, such as the mollusks and barnacles of the preshoal environment, are noticeably absent, and even the foraminiferal population is smaller than in the other environments. Although there is a slightly greater abundance of Foraminifera on the sheltered slope than on the crest, the distribution is still sporadic. Only a few of the species present on the current slope are found on the shoal crest and sheltered slope. Thus, very little of the preshoal fauna is found on the crest and eastern side of the shoal.

\section{CONCLUSIONS}

The northward-setting water masses emerging from Bering Strait are characterized by a divergence and associa ted decrease of speed. Only the divergence within the coastal water near Cape Prince of Wales, which is considered to be actively supplying sediment to the shoal, is thought to be a significant control of sedimentation.

It has been shown that the coastal water passing around the Cape has a high concentration of suspended sediment. The divergence in the water mass north of the Cape tends to reduce the concentration of material, and deposition occurs. A channeling effect is produced by the strong current in the transition zone to the west, which tends to retard the westward migration of the main dispersal route and the accompanying depositional area.

That part of the nor thward-setting coastal water that passes northeastward onto the crest of the shoal undergoes some modifications; the most significant of these is the disappearance of its density stratification. Probably the chief mechanism mixing the water mass is wave action on the shallow crest. The wave action also increases the vertical turbulence of the water column and permits the picking up of bottom material along the crest. It appears that the sand is left as a winnowed lag deposit while much of the finer sediment is retained in suspension and moved to the sheltered slope. The illdefined eddy behind the shoal may help keep some material from being carried farther 
away. The progressive decrease in grain size, to be expected under these conditions, occurs in the bottom sediments down to the grade of medium silt. Finer particles are retained in suspension by the mixing action.

Although the main path of sediment transport, as governed by the current, appears to be northward along the current slope, it is apparent that some of the shoal sediment invades the preshoal environment. This westward encroachment of the shoal into the preshoal area is also suggested by the slight shift in the shoal axis near the distal end (fig. 2, left). The effect of the bathymetry of the shoal on the path of the current governing deposition in the area studied is shown in figure 5 (right), and significant changes in bathymetry would be expected to change the current pattern which, in turn, would cause a change in depositional areas. Thus, it is apparent that although the shoal and its sedimentary environments are controlled by the physical environments, the distribution of the physical environments can be altered by a long-range cumulative change in the sedimentary environments.

Finally, it should be pointed out that a shoal can be defined as a bathymetric feature which may be a result of sediment deposition. A shoal delimited on a chart by isobaths is usually a conspicuous feature (fig. 2, $l e f t$, but the existence of shoals in the geologic past cannot be thus detected. The identification of a shoal merely on the basis of the sediment statistics may be a difficult task. The chart of mean grain size of Cape Prince of Wales Shoal (fig. 6, left) fails to reveal the presence of a spitlike shoal covering approximately 2,000 square miles. For this reason, the sedimentary environments, as determined by grain size, sorting, and mineralogical and faunal composition, must be interpreted in terms of the influence of the physical processes in the environment.

\section{A NOTE ON DURATION OF ENVIRONMENTS}

The various sedimentary environments that have been described are governed by the relative intensity and dominance of the physical processes that influence sediment dispersal. These processes vary slightly but continuously, but in this region where the sea is ice-covered for 7 or 8 months of the year the annual variations can be very large. During winter the effects of waves on the environments is small. Current velocities and the sediment transport that can be maintained by currents are sharply reduced. Temperature, salinity, and density distributions are changed. The influx of sediment from the rivers stops. Thus, during the period of ice cover, the lower-energy potential of the physical processes cannot effect the sedimentary environments to the same degree as during the ice-free period. The period of ice cover may simply be a time of nondeposition, or it may be a time of deposition of materials of different composition, probably the finer silts, clay particles, and micas. The abundance of mica in places on the sheltered slope near the crest may represent deposition during the period of ice cover. Deposits during this part of the year would form in the lower-energy physical environment, would be less abundant than deposits during ice-free sedimentation, and might be subsequently modified by the higher energies of the ice-free period. Nevertheless, the possibility that sedimentation occurs under both these sets of physical conditions should be recognized.

AckNowLEDGMENTs.-This report was supported in part by U.S. Atomic Energy Commission Contract AT(45-1)-540 and the Office of Naval Research Contract Nonr-477(10), Project NR 083012 , with the University of Washington. A preliminary report on this study, under the title "Offshore Current Control of Sedimentary Environments Associated with Large Underwater Shoals," was presented at the Tenth Pacific Science Congress of the Pacific Science Association, held at the University of Hawaii, Honolulu, August 21 to September 6, 1961, and sponsored by the National Academy of Sciences, the Bernice Pauahi Bishop Museum, and the University of Hawaii. 


\section{REFERENCES CITED}

Barnes, C. A., and Thompson, T. G., 1938, Physical and chemical investigations in the Bering Sea and portions of the North Pacific Ocean: Univ. Washington Pubs. in Oceanography, v. 3, p. 35-79.

Bufrington, E. C., Carsola, A. J., and Dietz, R. S., 1950, Oceanographic cruise to the Bering and Chukchi Seas, summer 1949, pt. 1, Sea floor studies: U.S. Navy Electronics Laboratory Rept. No. 204, 26 p.

Flemrng, R. H., and Stafr, 1959, Oceanographic survey of the eastern Chukchi Sea, 1 August to 2 September 1959, Preliminary report of Brown Bear cruise no. 236: Seattle, Univ. Washington Dept. Oceanography, $36 \mathrm{p}$.

—_ - 1960, Preliminary report of Brown Bear cruise no. 268, second oceanographic survey of the Chukchi Sea, 26 July to 28 August 1960: Seattle, Univ. Washington Dept. Oceanography, $11 \mathrm{p}$.

HeLLAND-HANSEN, BJ., 1918, Nogen hydrografiske metoder: Förhändlingar redenskapelig Skandinaviske Naturforsker möte, Juli 1916, p. 357.

LaFond, E. C., Dietz, R. S., and Pritchard, D. W., 1949, Oceanographic measurements from the U.S.S. Nereus on a cruise to the Bering and Chukchi Seas, 1947: U.S. Navy Electronics Laboratory Rept. No. 91 (restricted), 96 p.

Maksmov, I. V., 1945, Determining the relative volume of the annual flow of Pacific waters into the Arctic Ocean through Bering Strait: Problemi Arktiki, v. 2 (English translation: Univ. Washington Library, Microfilm no. 23f, 13 p.).

OzTurgot, E., 1960, Currents and related water properties in the Eastern Chukchi Sea: unpublished Master's thesis, Dept. Oceanography, Univ. Washington, $60 \mathrm{p}$.

Saur, J. F. T., Tuliy, J. P., and LaFond, E. C., 1954, Oceanographic cruise to the Bering and Chukchi Seas, summer 1949, pt. 4, Physical oceanographic studies; descriptive report: U.S. Navy Electronics Laboratory, v. 1, 31 p. 